\title{
A Comparative Study of Traditional vs. Work from Home Among the Employees Working from Home During COVID-19 Crisis in Raigad and Udham Singh Nagar
}

\author{
Yogita M. Patil $^{1 *}$, Namit Bhatnagar ${ }^{2}$ \\ ${ }^{l}$ Lecturer, Department of Commerce, Shri D.D. Vispute College of Science, Commerce and Management, \\ Navi Mumbai, India \\ ${ }^{2}$ Educator, Department of Commerce, Kumaun University, Kashipur, India \\ *Corresponding author: yogitamp04@gmail.com
}

\begin{abstract}
This study is related to the outbreak of COVID 19 pandemic in India, how the widespread of this virus has forced individuals to be locked in our homes which has drastically affected the growth of our economy. Not only India, the world is facing the COVID 19 catastrophe which has shut down all the professionals and business enterprises. Since the COVID 19 is a very contagious virus and it is incurable till date and curable with limited scope, hence WHO published the advisory stating that till the pandemic is dealt with every individual must maintain social distance in order to slow down the rate of spread of COVID 19.

In this world of technological advancement and better traveling equipment, the world is nothing but a global village and since, if one part of the economy is getting affected, it has a large scale impact on all over the world. However, "Janta Curfew" has been implemented, it has become more challenging for the employees to visit workplaces. The study will detail about analysing the aspect of work from home facilities during the lockdown period.

(The data is based on during the first lockdown period from March to June)
\end{abstract}

Keywords: Business environment, COVID 19, Janta curfew, Pandemic, Social distancing, WHO.

\section{Introduction}

Coronavirus disease (CoVID-19) is an infectious disease caused by a new virus. The disease causes respiratory illness (like the flu) with symptoms such as a cough, fever, and in more severe cases, difficulty breathing. You can protect yourself by washing your hands frequently, avoiding touching your face, and avoiding close contact ( 1 meter or 3 feet) with people who are unwell.

Coronavirus disease spreads primarily through contact with an infected person when they cough or sneeze. It also spreads when a person touches a surface or object that has the virus on it, then touches their eyes, nose, or mouth.

The outbreak of the novel coronavirus (CoVID-19) and the subsequent work-from-home imperatives and lockdowns have led to significant economic disruptions around the world. As several millions of workers across diverse sectors are asked to self-quarantine, an understanding of the impact of this shift and mitigation strategies becomes critical. In India, the first case of CoVID 19 virus was detected in January end and we started to see an increase in the number of cases from March 12th 2020, according to a report of World Health Organization, the growth rate of CoVID 19 is very exponential and since it is very contagious and somewhat life-threatening, the practice of social distancing must be followed in every work environment. However, you cannot follow social distancing if you are working in an office since the interaction between people is a lot in the work environment, maintaining social boundaries looks kind of possible, so in order to fight with the spreading virus and practising the social distancing Hon. Prime Minister Narendra D. Modi as a drill implemented "Janta Curfew" on 22nd March 2020 to make people aware of the need for social distancing in order to fight the CoVID 19.

After the Janta Curfew was successfully implemented and meanwhile the cases for CoVID 19 were piling up day by day, to slow the rate of infection the LOCKDOWN was initiated in the entire country for a period of 21 days so that the community transmission couldn't be triggered and our health system could work effectively and not collapse.

But likewise, work is also an important aspect to survive in society, so there was a dilemma across the organizations of the world, how do we work and follow lockdown all at the same time? The solution to which was Work from Home. We live in an era where smartphones are getting smarter day by day and the Internet is dominating the work, our reliance is so much that without the internet in the workplace is like running a race with one leg fractured. So the idea of Work from Home was feasible since most works could be communicated through the Internet. Most firms in the business have prioritized their employee's health's first rather than the targets and permitted work from home. In this study, we will be analysing the advantages and 
disadvantages of work from home and which approach of working is good according to the employees.

For the sample selection, we have considered two districts Raigad (A district in Maharashtra) and Udham Singh Nagar (A district in Uttrakhand)

Raigad District: An official Census 2011 detail of Raigad, a district of Maharashtra has been released by Directorate of Census Operations in Maharashtra. Enumeration of key persons was also done by census officials in Raigad District of Maharashtra.

In 2011, Raigad had a population of 2,634,200 of which male and female were $1,344,345$ and $1,289,855$ respectively. In the 2001 census, Raigad had a population of 2,207,929 of which males were 1,117,628 and the remaining 1,090,301 were females. Raigad District population constituted 2.34 per cent of total Maharashtra population. In the 2001 census, this figure for Raigad District was at 2.28 per cent of Maharashtra population.

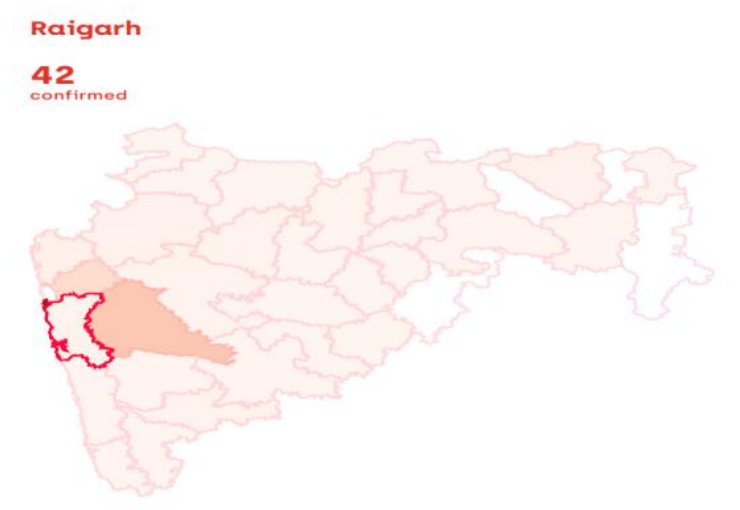

There was a change of 19.31 per cent in the population compared to the population as per 2001. In the previous census of India 2001, Raigad District recorded an increase of 20.99 per cent to its population compared to 1991. What is the population of Raigad in 2020? The fact is, the last census for Raigad district was done only in 2011 and the next such census would only be in 2021. But as per estimate and projection, the population of Thane district in 2018 is 29.36 Lakhs compared to 2011 census figure of 26.34 Lakhs.

Average literacy rate of Raigad in 2011 was 83.14 compared to 77.03 in 2001. If things are looked at gender wise, male and female literacy were 89.13 and 76.92 respectively. For the 2001 census, the same figures stood at 86.15 and 67.75 in Raigad District.

Total literate in Raigad District were 1,939,994 of which male and female were 1,059,692 and 880,302 respectively. In 2001, Raigad District had 1,458,324 in its district.

With regards to Sex Ratio in Raigad, it stood at 959 per 1000 male compared to 2001 census figure of 976 . The average national sex ratio in India is 940 as per latest reports of Census 2011 Directorate. In 2011 census, child sex ratio is 935 girls per 1000 boys compared to figure of 939 girls per 1000 boys of 2001 census data.
If we talk about the outbreak of CoVID 19 virus in the district of Raigad we can assume that since the testing process is still ongoing, no concrete figures are provided regarding the Raigad District, till date no cases have been reported but as the trend follows up in Maharashtra as per 10/04/2020 1734 active cases are reported in Maharashtra whereas more than 30000 has been tested and only 188 got recovered. On the mourning part 110 also lost their lives while battling the CoVID 19 and Pune which is sharing its border from Raigad district has 42 active cases which constitute $0.9 \%$ cases from Maharashtra.

Udham Singh Nagar: An official Census 2011 detail of Udham Singh Nagar, a district of Uttarakhand has been released by the Directorate of Census Operations in Uttarakhand. Enumeration of key persons was also done by census officials in Udham Singh Nagar District of Uttarakhand.

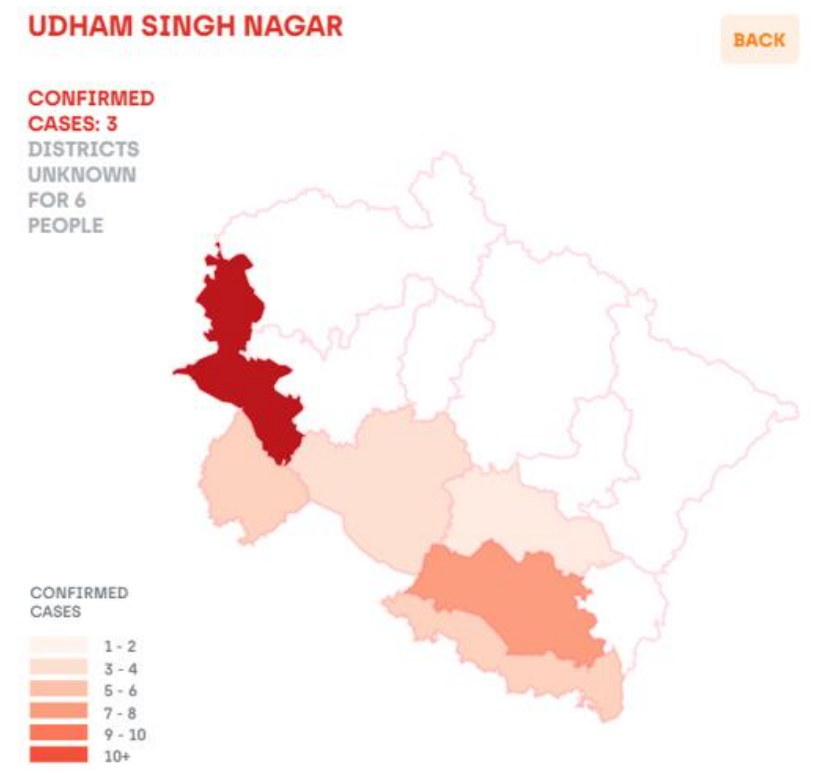

In 2011, Udham Singh Nagar had a population of 1,648,902 of which male and female were 858,783 and 790,119 respectively. In the 2001 census, Udham Singh Nagar had a population of $1,235,614$ of which males were 649,484 and remaining 586,130 were females. Udham Singh Nagar District population constituted 16.35 per cent of total Maharashtra population. In the 2001 census, this figure for Udham Singh Nagar District was at 14.55 per cent of Maharashtra population.

There was a change of 33.45 per cent in the population compared to the population as per 2001. In the previous census of India 2001, Udham Singh Nagar District recorded an increase of 33.60 per cent to its population compared to 1991.

What is the population of Udham Singh Nagar in 2020? The fact is, the last census for Udham Singh Nagar district was done only in 2011 and the next such census would only be in 2021 . But as per estimate and projection, the population of Thane district in 2018 is 19.77 Lakhs compared to 2011 census figure of 16.49 Lakhs.

With regards to Sex Ratio in Udham Singh Nagar, it stood at 920 per 1000 male compared to 2001 census figure of 902 . The 
average national sex ratio in India is 940 as per latest reports of Census 2011 Directorate. In 2011 census, child sex ratio is 899 girls per 1000 boys compared to figure of 913 girls per 1000 boys of 2001 census data.

Average literacy rate of Udham Singh Nagar in 2011 was 73.10 compared to 64.86 of 2001. If things are looked at gender wise, male and female literacy were 81.09 and 64.45 respectively. For the 2001 census, the same figures stood at 75.22 and 53.35 in Udham Singh Nagar District. Total literate in Udham Singh Nagar District were 1,037,839 of which male and female were 598,525 and 439,314 respectively. In 2001, Udham Singh Nagar District had 659,165 in its district.If we talk about the outbreak of CoVID 19 in the state of Uttarakhand till date 35 cases have been reported and 1688 has been tested, however, there has been no loss of life in Uttarakhand. Udham Singh Nagar has reported 3 active cases and testing is still going on so numbers aren't concrete evidently.

\section{Need for Study}

- To find the feasibility of work from home facility.

- Satisfaction level among workers.

- To check organization and employee relationship.

- To check the impact on salary and other incentives.

- Whether such facilities the company should adopt during a crisis.

\section{Statement of Problem}

- To study the Employee's perspective regarding Work from Home in Raigad and Udham Singh Nagar.

- To study the practicality of Work from Home in Raigad and Udham Singh Nagar.

- To study the employee's preferences regarding Work Environment i.e. what will they prefer: Traditional Workplace or Work from Home, in Raigad and Udham Singh Nagar.

\section{Objectives}

- To analyse the perquisites of Work from Home (if any) in the time of CoVID crisis.

- To analyse how effectively the Work from Home can be implemented in the organizations.

- To look out about if Work from Home could be an effective working tool in the post-crisis world.

- To have an employee's viewpoint and preferences over Traditional Workplace and Work from Home.

\section{Hypothesis}

H0 - Employees are not satisfied with the Work from Home facility in respect of Raigad and Udham Singh Nagar District.

H1 - Employees are satisfied with the Work from Home facility in respect of Raigad and Udham Singh Nagar District.

H2 - Implementation of Work from Home even after the
CoVID 19 crisis in Raigad and Udham Singh Nagar District.

\section{Advantages of Traditional Workplace}

\section{1) Focused and Working Environment}

In order to be productive and efficient in the work, the focus is must and to provide a distraction-free ecosystem nothing is better than the dedicated workplace where everything is workoriented.

2) Better Coordination between the levels of Management

When you are working at a dedicated place and everyone out there is pursuing the same motive as you, there cease to exist better coordination between various levels of management.

3) Compartmentalization of Personal and Professional Lives

No one likes to indulge their personal lives with their professional ones, it causes chaos to work and working in the traditional workplace can eliminate this variable since it is work-oriented.

\section{4) Better Social Relations}

Not only productive work is achieved in the traditional workplace but also better social relations between your teammates, your clients and your leaders are formed since you interact with all of them on a repetitive basis

\section{Disadvantages of Traditional Workplace}

\section{1) Rigid working hours}

Traditional Workplaces have very rigid working hours which makes the overall day pretty packed for an employee and he has to sacrifice all the other priorities.

2) Increment in Travelling Expenses

Travelling from home to work by any means will increase your expenses which will cause a reduction in your savings.

3) Informal Working Environment

Whereas work from home will focus more on to the point work rather than grapevine communication or chats between colleagues.

\section{Disadvantages of Work from Home}

\section{1) Lack of coordination between the teams}

Since you are working from your home and there is a lack of communication between you and your team, it will act as a communication barrier and work might not run out seamlessly.

2) Time-consuming Practice

When you have a dedicated time allotted to your work, you can squeeze the remaining time entertaining your other priorities, but while working from home, you don't know what time you can work since many distractions will blend in between you and your work which can decrease your output and increase the time taken to complete a task.

\section{3) Lack of Accountability}

Due to no supervision, the employees might procrastinate the work and be held less accountable with respect to the work provided to them. Which could lead in the improper and ineffective workflow hence increasing the labour hours for nontechnical reasons. 
Table 1

\begin{tabular}{|l|l|l|}
\multicolumn{1}{|c|}{ Sample selection } \\
\hline Particulars & $\begin{array}{c}\text { Raigad } \\
\text { (Navi Mumbai) }\end{array}$ & $\begin{array}{c}\text { Udham Singh Nagar } \\
\text { (Uttrakhand) }\end{array}$ \\
\hline Area & 7152 sq.kms & 2542 sq.kms \\
\hline Total population & $26,34,200$ & $16,49,165$ \\
\hline Population growth & $19.31 \%$ & $33.45 \%$ \\
\hline Total population (males) & $13,44,345$ & $8,57,452$ \\
\hline Total population (females) & $12,89,855$ & $7,91,713$ \\
\hline Sex ratio & $959 / 1000$ & $920 / 1000$ \\
\hline Male literacy & $89.13 \%$ & $81.09 \%$ \\
\hline Female literacy & $76.92 \%$ & $64.45 \%$ \\
\hline Average literacy & $83.14 \%$ & $73.10 \%$ \\
\hline
\end{tabular}

\section{Sources of Data Collection}

The aforesaid research is to be conducted by the means of descriptive quantitative research methods with reference to data collections. Both primary and secondary data will be collected.

Primary data:

Primary Data will be collected from the local consumers by the way of Questionnaire Method and Personal Interviews.

Data has been collected from the samples who are working in the corporate sectors. The concreteness of the work regarding the management of the office has been checked by collecting questionnaires via google forms. So several questions were put forward and samples responded for the same.

Secondary data:

Secondary Data will be collected by past manifestations and goals covered in lieu of, leading research papers, websites and other research centres.

Data of CoVID 19 is collected from websites and newspapers which has been analysed by the researchers and all the data entries have been cross verified to ensure the reliability and authenticity of the information provided.

\section{Statistical Tools Used for Data Analysis}

The data will be combined in the simple and easy words and numerical data would be converted into easy words for better and precise understanding. Final data will be presented with diagrams, charts, graphs, tables, etc., with appropriate explanation. Data Analysis will be done by the content quantification, Google Docs, Google Forms and sorting the data by using the tabulation method, for which Microsoft Excel will be used. The final result will be found by Thematic coding and decoding and then testing hypotheses through F-test, and to test the intensity of relation ANOVA will be used.

\section{Data Interpretation}

In the survey of samples in Raigad and Udham Singh Nagar together, people were asked about their point of view on traditional workplace and work from home. All the people included in the survey are from Raigad and Udham Singh Nagar or outskirts. All of them are working professionals and practice traditional work in their day to day lives.
1) During the time of crisis of CoVID 19, is your organization providing you with the facility to work from home?

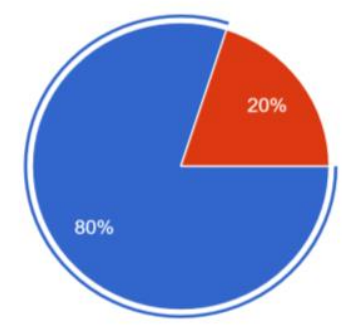

When People were asked about if in this time of crisis their organization is providing the facility of working from home in the districts of Raigad and Udham Singh Nagar, $80 \%$ said Yes and $20 \%$ said No. i.e. only $80 \%$ of the organisations supported the facility of work from home.

2) How many positive CoVID cases are reported in your organization?
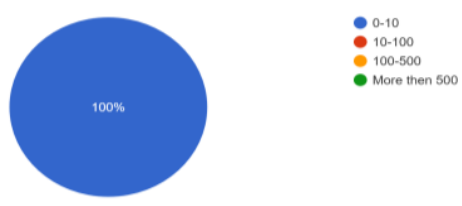

When the locals were asked about the number of Positive cases in the area of Raigad and Udham Singh Nagar, 100\% people were confident that till date there has been no case of CoVID 19 in their locality or surroundings or workplace, still, Work from Home was granted for precautionary basis.

3) Where do you find a more friendly working environment?
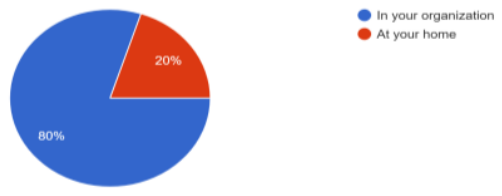

On asking about the favourite place to work from the people of Raigad and Udham Singh Nagar it was obtained that $80 \%$ prefer working in the organization and $20 \%$ prefer working from their homes only, i.e. the majority of people prefer traditional workplaces.

4) During work from home, are you facing any deductions regarding your salaries?
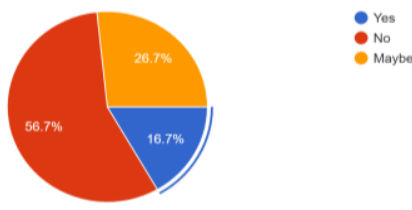

Remuneration is the motivation everybody likes it, so when people of Raigad and Udham Singh Nagar were asked about if they are facing any deductions regarding salaries during this LOCKDOWN situation. $16.7 \%$ said yes, $26.7 \%$ were not sure about it and $56.7 \%$ didn't face any deductions, i.e. majority of people were happy with the salaries provided to them even in 
the time of crisis.

5) Do you get the right amount of support and guidance from your supervisor during Work from Home?

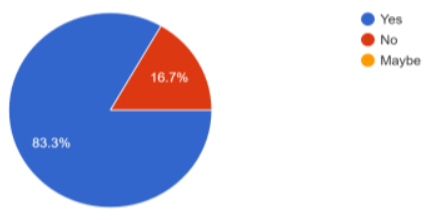

When asked about the support and guidance from their supervisor during Work from Home, by the people of Raigad and Udham Singh Nagar $83.3 \%$ were satisfied with the guidance provided while $16.7 \%$ faced problems in support and guidance, i.e. the majority of employees were able to work seamlessly amid lockdown.

6) "I have adequate opportunities to develop professional skills while working from home"
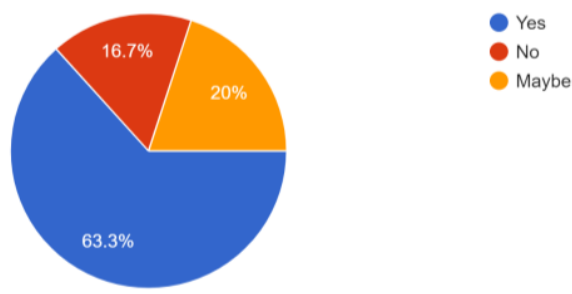

We asked the people of Raigad and Udham Singh Nagar if they had adequate opportunities to develop professional skills while working from home, $63.3 \%$ people said Yes they developed some skills, while $20 \%$ were not confident about it and $16.7 \%$ said No they didn't have any opportunity.

7) "I feel easy to communicate with all levels of the organization"

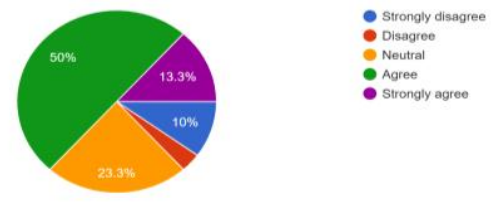

In this period of Work from Home when people of Raigad and Udham Singh Nagar were asked if they had any problems regarding communicating at any level of the organization following was the outcome of the people, 50\% are agreed that they didn't have any issues in communicating with the levels of organisations. $23 \%$ are neutral for the question. $13.3 \%$ strongly agreed with the question.

8) Are you experiencing any co-ordinating issues with your co-workers during work from home?

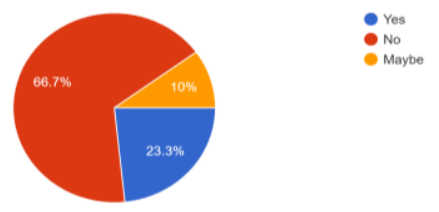

When people of Raigad and Udham Singh Nagar were asked if they are experiencing any co-ordinating issues with their coworkers during work from home. $66 . \%$ of the people were positive about the effective co-ordinating while working from home, $10 \%$ were a bit paranoid about the coordinating and $23.3 \%$ faced the problem of ineffective coordination amid lockdown work from home.

9) Are you experiencing any technical issues at home during work from home? If yes, what are they?

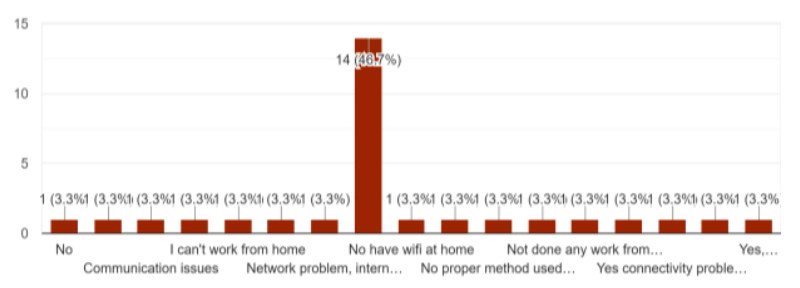

When people were asked if they were facing any difficulties regarding the technical issues at home during work from home, mixed statements were received, a majority of people complained about not having wi-fi at homes., while many people were facing the communication issues such as network and connectivity problems due to lack of service providers because of lockdown.

10) "I get appreciation from my immediate supervisor"

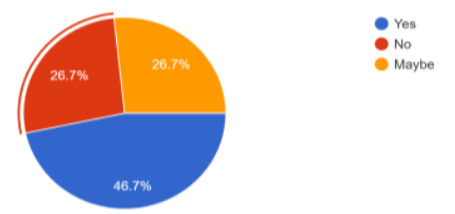

When the samples were asked whether they are getting appreciation from their immediate supervisor, $46.7 \%$ have put a tick against yes with the mail they are getting appreciated and $26.7 \%$ are working but they are not being appreciated, $26.7 \%$ are neutral respondents.

11) In future, what will you prefer? Why? (After the CoVID crisis)

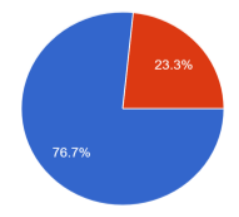

- Traditional Workplace
- Work From Home

When asked from the people regarding their favourite spot to work after the closure of lockdown, 76.7\% people said they would prefer a traditional workplace, while $23.3 \%$ of people prefered Work from Home. Traditional Workplaces will be preferred the most.

Due to the various factors such as:

1. For the dedication to the workplace

2. Difficulty balancing personal and professional life.

3. Inability to maintain the workflow 


\section{Conclusion}

The main motive to go through this topic was to analyse the workflow an individual can generate while Working from Home. We were curious to know about if the work could only be performed in the designated workplace or one could breach the barrier and work on their own terms yet be productive to the organization they are serving. Due to the outbreak of CoVID 19 , there is an opportunity to find out if the traditional workplaces are effective or not.

So, we reached the conclusion that a majority of employees were satisfied with the Work from Home facility during such a crisis, thus H1 is accepted. But this is only due to the dear of CoVID 19, otherwise, most of the people want to perform their work in their designated office premises. However, since most of the persons were satisfied with work from home facility amid lockdown and CoVID 19 terror in the districts of Udham Singh Nagar and Raigad, thus H0 is rejected. On analysing the responses, we got, most of the employees were satisfied with the work from home facility only during lockdown period, however, majority of people still prefer their old traditional workplace to work around, thus $\mathrm{H} 2$ is rejected.

During such crises organisations should provide work from home facilities and support the decisions of our government regarding the rules of lockdown to overcome such issues as soon as possible. Which will result in the overall development of the economy rather than the situations like inflation, unemployment and this CoVID 19 pandemic? Moreover, the organizations should provide the employees with the facilities like laptops, internet and flexible working hours which will lead to the smooth functioning of work and objectives of organisations will get fulfilled along with the objectives of the nation.

\section{References}

[1] https://www.thehindu.com/opinion/op-ed/work-from-home-in-the-timeof-covid-19/article31207008.ece

[2] https://stat.international/the-benefits-of-traditional-offices-and-virtualoffices/

[3] https://usnagar.nic.in/about-district/

[4] https://raigad.gov.in/en/demography/

[5] https://www.census2011.co.in/search.php?cx=partner-pub$0612465356921996 \% 3$ A9964620645\&cof=FORID\%3A10\&ie=UTF$8 \& \mathrm{q}=$ Udham + Singh + Nagar $\& s a=$ Search $\&$ siteurl $=$ www.census 2011. co.in \%2Fdistrict.php\&ref=www.census2011.co.in\%2F\&ss=3066j654344j20

[6] https://www.covid19india.org/

[7] https://www.thoughtco.com/null-hypothesis-examples-609097 